\title{
Chemical Composition and Bioactivity of Essential Oils and Extracts from Oregano from Madeira Island, Portugal
}

\author{
P.C. Castilho ${ }^{1}$, T.S. Weinhold ${ }^{1}$, S.C. Gouveia ${ }^{1}$, S. Savluchinske-Feio ${ }^{2}$, P.T. Pereira ${ }^{2}$, \\ A.I. Rodrigues ${ }^{3}$ and F. Venâncio \\ ${ }^{1}$ Centro de Química da Madeira, Departamento de Química, Universidade da Madeira, \\ Campus da Penteada, 9000-390 Funchal, Portugal \\ ${ }^{2}$ INETI - Departamento de Biotecnologia, Estrada ao Paço do Lumiar 1699-038 Lisboa, \\ Portugal \\ ${ }^{3}$ INETI - DTIQ, Estrada ao Paço do Lumiar 1699-038 Lisboa, Portugal
}

Keywords: Origanum virens, composition, antioxidant, antibacterial, hexacosanol

\begin{abstract}
In the course of ongoing investigations on polymorphic Lamiaceae species, we studied Origanum vulgare spp. virens growing wild in several locations of Madeira Island, Portugal. Variation in essential oil composition with climate conditions was studied. The antimicrobial activity of the various essential oils was determined against 10 strains of bacteria and yeasts, usually found as human pathogenic or food contaminants. The essential oils inhibited all the bacteria tested excepting for $P$. aeruginosa. The most sensitive microorganism was $M$. smegmatis with $\mathrm{MIC}=25 \mu \mathrm{g}$ $\mathrm{ml}^{-1}$ for two of the oils. The results of this study suggest a potential application of these oils in preventing the human pathogenic and food contaminant microorganisms growth. Radical scavenging capacity of essential oils and solvent extract (hexane, chloroform, ethyl acetate and methanol) were also determined, since interest of oregano resides in both non polar and polar fractions, all known by their very high antioxidant activity. From the hexane fraction, we obtained a large amount of 1-hexacosanol, $\mathrm{C}_{26} \mathrm{H}_{54} \mathrm{O}$, a long chain alcohol, which was previously extracted in the non-esterified form only from Hygrophila erecta.
\end{abstract}

\section{INTRODUCTION}

Origanum vulgare L. subsp. virens (Hoffmanns. \& Link) Ietsw. (sometimes called the Moroccan origanum) is the common oregano that thrives naturally in almost every region of Portugal, especially on the edges of fields, on dry and uncultivated or waste ground. In Madeira island, it is very common in the edges on paths in the Laurisilva forest, up to $1100 \mathrm{~m}$ of altitude.

The antimicrobial properties of volatile aromatic oils and medium-chain fatty acids derived from edible plants have been recognized since antiquity. Origanum oil used as food-flavouring agent, possesses a broad spectrum of antimicrobial activity due, at least in part, to its high content of phenolic derivatives, such as carvacrol and thymol (Preuss et al., 2005). Earlier studies have demonstrated the ability of origanum oil to retard and inhibit the growth of various food spoiling organisms including the species of Aspergillus (mycotoxinogenic filamentous fungi) and industrial yeasts (Manohar et al., 2001). Origanum oil completely inhibited the growth of Candida albicans at $0.25 \mathrm{mg} / \mathrm{ml}$. Origanum oil was the most potent of the essential oils tested and proved to be bactericidal in culture to two strains of Staphylococcus aureus at $0.25 \mathrm{mg} / \mathrm{ml}$.

The current trend adopted by food production, legislative offices and consumers has demanded a progressive retreat of chemical additives in food conservation systems, searching alternative substances in order to preserve final products from food spoilage and diseases caused by microorganisms and oxidation.

The present work was undertaken to determine the chemical composition of essential oils from origanum growing wild in several locations of Madeira island, to evaluate any relationships between composition and the phytoclimatic platforms established for Laurisilva forest, and to evaluate the radical scavenging capacity and the antimicrobial activity towards human pathogenic and food spoilage fungi and bacteria, in 
the search for new substances as alternative to the commercial preservatives.

\section{MATERIALS AND METHODS}

\section{Plant Material}

Origanum vulgare spp. virens samples were collected in several locations of Madeira island, Portugal. Aerial parts were dried in well ventilated spaces away from sun light.

\section{Essential Oils Isolation}

Air-dried plant materials were submitted hydrodistillation according to European Pharmacopea, using a Clevenger type apparatus. The essential oils amounts were determined gravimetrically.

\section{Essential Oils Analysis}

Qualitative and quantitative analyses of the essential oils were carried out using a Hewlett-Packard 6890 Series GC system, equipped with a two towers automatic injector, operating in split mode injector $\left(240^{\circ} \mathrm{C}\right)$ and a flame ionization detector $\left(250^{\circ} \mathrm{C}\right)$.

Helium was used as carrier gas $(1 \mathrm{ml} / \mathrm{min})$, and the two capillary columns were a OVO1 $(50 \mathrm{~m} \times 0.25 \mathrm{~mm}$; film thickness, $0.25 \mu \mathrm{m})$ and a SupelcoWax $10(30 \mathrm{~m} \times 0,25$ $\mathrm{mm}$, film thickness $0.25 \mu \mathrm{m})$. The temperature programs were $70^{\circ} \mathrm{C}$ during 5 minutes then increase $70-230^{\circ} \mathrm{C}$ at a rate of $2^{\circ} \mathrm{C} / \mathrm{min}$, split ratio, $1: 10$. Identification of compounds was based on their retention indices (RIs) and mass spectra obtained with a Varian Saturn 3 system operating in EI mode at $70 \mathrm{eV}$ and identical chromatographic conditions.

\section{Preparation of Extracts}

The air-dried powdered aerial parts were successively extracted at room temperature with petroleum ether, chloroform, ethyl acetate and methanol. Chlorophylls were removed with activated charcoal and the solvents evaporated under reduced pressure, at room temperature. During the solvent evaporation of the hexane extracts of all plant materials, white crystals of melting point $77-78^{\mathrm{a}} \mathrm{C}$ were formed. These were filtered and characterized, being identified as n-hexacosanol (ceryl alcohol).

\section{Antioxidant Activity}

The Free Radical Scavenging Capacity (RSC) was evaluated by measuring the scavenging activity of the examined essential oils and extracts on 2,2-diphenyl-1picrylhydrazil (DPPH) radicals.

The DPPH assay was performed as described before. 5 solutions of TROLOX (concentrations ranging from 0.005 to $0.025 \mu \mathrm{mol}$ ) were made to react with DPPH used to establish a calibration curve. The disappearance of DPPH colour was read spectrophotometrically at $515 \mathrm{~nm}$ using a Perkin-Elmer Lambda 2 spectrophotometer. The samples (accurately weighted) were mixed with $1 \mathrm{ml}$ of $90 \mu \mathrm{M}$ DPPH solution and the volume was adjusted to $4 \mathrm{ml}$ with $\mathrm{MeOH}$ p.a. For each sample, the absorbance of four replicates was recorded. The RSC is expressed as $\mu$ mol Eq. Trolox $/ 100 \mathrm{~g}$ of sample using the regression equation, obtained from the calibration curve:

$$
y=-10.63 x+0,4701\left(R^{2}=0,9978\right)
$$

\section{Microorganisms}

Bacteria: Escherichia coli CCMI 270, L. monocytogenes (isolated from cheese of São Jorge island, Azores, Portugal) Micrococcus luteus CCMI 322, Mycobacterium smegmatis CCMI 690, Pseudomonas aeruginosa, Staphylococcus aureus CCMI 335, Streptococcus faecium CCMI 338. Yeasts: Candida albicans CCMI 209, Debaryomyces kloackeri CCMI 157, Rhodotorula rubra CCMI 43. They were obtained from the Culture Collection of Industrial Microorganisms (CCMI) Laboratório de Microbiologia Industrial, Lisbon, Portugal. 


\section{Incubation Conditions}

Brain Heart Infusion (Merck) was used as culture medium for bacteria whereas Malt extract (Merck) was used for fungi.

The temperature and incubation time was variable according to the microorganism requirements. M. luteus was incubated at $30^{\circ} \mathrm{C}$ for $24 \mathrm{~h}$. C. albicans was incubated $30^{\circ} \mathrm{C}$ for $48 \mathrm{~h}$ whereas $D$. kloackeri and R. rubra were incubated for $72 \mathrm{~h}$ at $30^{\circ} \mathrm{C}$. The other microorganisms were incubated at $37^{\circ} \mathrm{C}$ for $24 \mathrm{~h}$.

\section{Screenings for Antimicrobial Activities}

The minimum inhibitory concentration (MIC) of the active compounds was determined by the broth dilution method (Muroi and Kubo, 1996). The follow concentrations $\left(\mu \mathrm{g} \mathrm{ml}^{-1}\right)$ were tested: $200,100,50,25,12.5$. After incubation for $24 \mathrm{~h}-48 \mathrm{~h}$ for bacteria, at $37^{\circ} \mathrm{C}$ the microbial growth was examined. The same procedure was performed for yeasts, except that D. kloackeri and R. rubra were incubated for $72 \mathrm{~h}$. The results are expressed in Minimal Inhibitory Concentration (MIC), the weakest concentration of the oils yielding no visible growth. The minimal bactericidal/fungicidal activities were determined by a sub-cultivation of the samples into normal culture media at appropriate temperature and incubation times. 5-Fluorocytosine (Sigma) was used as a synthetic antimycotic for a positive control, whereas Rifampicin (Sigma) was used as antibiotic positive control. The MIC of each compound was determined at least twice. Essential oils from samples 2 to 5, were used in this study. Sample $4 \mathrm{~b}$ was used in this work, i.e., essential oil of flowers of the plants collected at location 4. The oils were dissolved in dimethylsulphoxide (DMSO) Merck, in order to obtain the following concentrations: $\left(\mu \mathrm{g} \mathrm{ml}^{-1}\right) 200,100,50,25,12.5$.

\section{RESULTS AND DISCUSSION}

Wild plants were collected in June 2006, in several locations of Madeira island in zones of protection of the Laurisilva forest, characterized by high rainfall and high relative humidity, between 500 and 1000 metres of altitude. Coordinates are shown in Table 1. Some variations in plant maturation were found, even though a direct correlation with altitude, humidity or sun light exposure was not possible to establish. Plants collected at Calheta and Santo da Serra (sample 2 and 5) had a much lower proportion of flowers (actually, bracts and flowers) to leaves than the other collections.

The content of the essential oils, expressed in $\mathrm{mg}$ of essential oil /100 g dry plant, is presented on Table 2. Table 3 shows the list the main chemical components of the investigated essential oils. The yield shows variations which reflect the proportion of flowers to leaves on the analysed samples. By separating one of the collections (4) into leaves and flowers ( $4 \mathrm{a}$ and $4 \mathrm{~b}$, respectively), we found that essential oil accumulates mainly in the flowers. The same tendency was found for n-hexacosanol isolated from the hexane extracts (Table 2)

Data for typical essential oil contents and composition of Origanum virens are not abundant although recently several papers related to this subspecies were published. Ferreira et al. (1998) refer that Origanum virens essential oil is not rich in carvacrol. However, Salgueiro et al. (2003) studied a carvacrol rich Origanum virens and its activity on Candida albicans.

It has been pointed out (Figueredo et al., 2006) that there are significant differences in the yield and composition of essential oils from populations of Origanum vulgare arising from environment factors, the most important of those being altitude, relating this to lack of water and short growing periods. Studies of Oreganum vulgare ssp. virens Ietswaart from Italy, France and Portugal revealed markedly different chemical compositions. The main constituents of the Italian oil were linalool $(10.1-70.1 \%), \beta-$ caryophyllene $(2.9-18.8 \%)$, carvacrol $(<0.1-13.7 \%)$, terpinen-4-ol $(<0.1-15.5 \%)$ and $\alpha$ terpineol $(<0.1-68.3 \%)$; and of the French oil, thymol (3.7-9.6\%), $\beta$-caryophyllene $(7.2-$ $10.6 \%)$, sabinene $(6.5-11.8 \%)$ and germacrene $\mathrm{D}(22.1-25.7 \%)$. Oil from Portugal differed from the others by the presence of greater amounts of the non-functionalized 
hydrocarbons $\delta$-elemene $(12.9 \%), \quad \beta$-caryophyllene $(11.1 \%), \quad \alpha$-terpineol $(9.2 \%)$, germacrene B $(6.6 \%),(E)-\beta$-ocimene $(6.6 \%)$ and $(Z)$ - $\beta$-ocimene $(3.7 \%)$. Ferreira et al. (1998) reported differences in essential oil composition depending on light and temperatures. Most of these studies refer to Mediterranean climate and its variations. In Madeira island, with a subtropical climate, some of these consideration do not apply altitude does not imply lack of water, always abundant, or light although it means a sharp decrease in average temperature. In general, it can be stated that all tested samples from Origanum virens growing wild in Madeira belong to a thymol rich chemotype. The most remarkable feature of these essential oils is their high contents in thymol methyl ether (1.84 up to $12.23 \%$ ) and carvacrol methyl ether. (1.19 to $4.36 \%)$. Indeed all our oils were richer in carvacrol methyl ether than carvacrol itself.

According to Figueredo et al. (2006) and references therein, the nine species from the Mediterranean under study show contents in these two ethers ranging from 0.1 to $0.5 \%$, trace in most samples. Only Hazzit et al. (2006) refer to plants with noticeable amounts of these ethers: an Origanum floribundun with $6.9 \%$ of carvacrol methyl ether and a Thymus guyonii presenting $10.7 \%$ of thymol methyl ether. High levels of thymol methyl ether $(16.3 \%)$, and carvacrol methyl ether $(11.4 \%)$ were found in $O$. vulgare ssp. gladulosum from Algeria (Houmani et al., 2002).

\section{Antioxidant Activity}

In the DPPH assay, the ability of the investigated essential oils and extracts to act as donors of hydrogen atoms or electrons in transformation of DPPH into its reduced form DPPH-H was investigated. All of the assessed samples were able to reduce the stable, purple-coloured radical DPPH into yellow-coloured DPPH-H. Despite variations in composition, the RSC of the essential oils was not much different from each other and did not reflect the amount of phenolic components, to which the RSC is usually attributed. All essential oils were more active than the extracts in chloroform, ethyl acetate or even methanol. As it can be observed in Table 5, the activities of the essential oils are in the range of $250 \mu \mathrm{mol}$ Eq. Trolox/100 g sample, while the average values found for RSC of solvent extracts were $150 \mu \mathrm{mol} \mathrm{Eq}$. Trolox/100 g for chloroform extracts, 120 for ethyl acetate and 110 for methanol.

\section{Antimicrobial Activity}

The essential oils of origanum were analyzed for antimicrobial activity against 4 gram-positive bacteria, 2 gram-negative bacteria, 1 fast-acid bacterium and 3 yeasts. All extracts showed moderate activity when compared to standard antibiotics (Table 4). The oils did not differ significantly in the activity against the tested microorganisms.

The structural requirements for the antimicrobial activity of carvacrol have been recently established (Veldhuizen et al., 2006), the presence of an aromatic hydroxyl group being essential for the activity, together with moderate hydrophobicity. The same considerations can be applied to thymol: both have been previously described as able to disrupt the bacterial membrane, by affecting both the $\mathrm{pH}$ gradient and the electron flow across the membrane (Helander et al., 1998).

The oils studied in the present work show similar activity, even though their content in carvacrol is very small, thymol being the major phenolic in all scrutinized samples. Recent studies (Sari et al., 2006) on O. gladulosum from Algeria report identical findings with a fairly similar susceptibility of gram-negative and gram-positive bacteria and yeast to all tested essential oil regardless of the predominance of thymol or carvacrol, and a very poor susceptibility of $P$. aeruginosa.

\section{CONCLUSIONS}

Wild Origanum virens from Madeira island belong to a thymol rich chemotype.

The essential oils and hexane extracts have greater radical scavenging capacity than the more polar extracts, probably due to the high contents in thymol, which demonstrated the highest activity in the DPPH assay. We hope to be able to follow this 
trend in the antimicrobial assays, even thought the bioactivity of thymol and carvacrol over a large range of microorganisms was not very different.

All origanum samples under study show a large content in non-esterified nhexacosanol, mainly accumulated in bracts and flowers.

\section{ACKNOWLEDGEMENTS}

The authors are grateful to programme INTERREG and FEDER, project Biopolis for financial support.

Thanks are due to Emanuel Camacho, Cátia Gomes and the high school students Alice Valente, Ana Paula Perestrelo, Catarina Lume, Maycoll Vieira and Juan Costa for their help in the field work, plant preparation and extraction, during OCJF2006 Ciência Viva project. They were the reason why we worked with oregano and it was their attention to detail that caught our attention to the large amounts of pure n-hexacosanol in this species.

\section{Literature Cited}

Ferreira, P., Gaspar, F., Sousa, C. et al. 1998. Origanum virens An oregano from Portugal, AIR - Agro Industrial Research, European Project AIR3CT93-0818, European Commission - DG XII - Science, Research and Development.

Figueredo, G., Cabassu, P., Chalchat, J.-C. and Pasquier, B. 2006. Studies of Mediterranean oregano populations, VIII - Chemical composition of essential oils of oreganos of various origins. Flavour and Fragr. J. 21: 134-139.

Hazzit, M., Baaliouamer, A., Faleiro, M.L. and Miguel, G. 2006. Composition of the essential oils of Thymus and Origanum species from Algéria and their antioxidant and antimicrobial activities. J. Agric. Food Chem. 54: 6314-5321.

Helander, I.K., Alakomi, H.L., Latva-Kala, K., Mattila-Sandholm, T., Pol, I., Smid, E.J. and Von Wright, A. 1998. Characterization of the action of selected essential oils on Gram-negative bacteria. J. Agric. Food Chem. 46:3590-3595.

Houmani, Z., Azzoudj, S., Naxakis, G. and Skoula, M. 2002. The Essential Oil Composition of Algerian Zaâtar: Origanum spp. and Thymus spp. J. Herbs, Spices \& Medicinal Plants 9(4): 275-280.

Manohar, V., Ingram, C., Gray, J., Nadeem, T., Echard, B., Bagchi, D. and Preuss, H. 2001. Antifungal activities of Origanum oil against Candida albicans. Molecular and Cellular Biochemistry 228: 111-117.

Muroi, H. and Kubo, I. 1996. Antibacterial activity of anacardic acid and totarol, alone and in combination with methicillin, against methicillin-resistant Staphylococcus aureus. J. Appl. Bacteriol. 80: 387-394.

Preuss, H., Echard, B., Dadgai, A., Talpur, N., Manohar, V., Enig, M., Bagchi, D. and Ingram, C. 2005. Effects of essential oils and monolaurin on Staphylococus aureus: In vitro and in vivo studies. Toxicology Mechanisms and Methods 15: 279-285.

Salgueiro, L.R., Cavaleiro, C., Pinto, E., Pina-Vaz,C., Rodrigues, A.G., Palmeira, A., Tavares, C., Costa-De-Oliveira, S., Goncalves, M.J. and Martinez-De-Oliveira, J. 2003. Chemical composition and antifungal activity of the essential oil of Origanum virens on Candida species. Planta Medica 69(9): 871-874.

Sari, M., Biondi, D.M., Kaâbeche, M., Mandalari, G., D’Arrigo, M., Bisignano, G., Saija, A., Daquino, C. and Ruberto, G. 2006. Chemical composition, antimicrobial and antioxidant activities of the essential oil of several populations of Algerian Origanum glandulosum Desf. Flavour Fragr. J. 21: 890-898.

Veldhuizen, E.J.A., Tjeerdsma-van Bokhoven, J.L.M., Zweijtzer, C., Burt, S.A. and Haagsman, H.P. 2006. Structural Requirements for the Antimicrobial Activity of Carvacrol. J. Agric. Food Chem. 54(5):1874-1879. 


\section{Tables}

Table 1. Geographic coordinates of collection points in the island of Madeira.

\begin{tabular}{lccc}
\hline Location & Latitude $(\mathrm{N})$ & Longitude $(\mathrm{W})$ & Elevation $(\mathrm{m})$ \\
\hline 1 Ponta do Pargo & $32^{\circ} 48^{\prime} 31.08^{\prime \prime}$ & $17^{\circ} 13^{\prime} 56.22^{\prime \prime}$ & 506 \\
2 Calheta & $32^{\circ} 47^{\prime} 09.81^{\prime \prime}$ & $17^{\circ} 10^{\prime} 19.17^{\prime}$, & 675 \\
3 Encumeada & $32^{\circ} 46^{\prime} 09,69^{\prime \prime}$ & $17^{\circ} 08^{\prime} 11.01^{\prime \prime}$ & 1001 \\
4 Ponta do Sol & $32^{\circ} 45^{\prime} 19.25^{\prime \prime}$ & $17^{\circ} 05^{\prime} 13.62^{\prime \prime}$ & 526 \\
5 Santo da Serra & $32^{\circ} 42^{\prime} 09.03^{\prime}$, & $16^{\circ} 45^{\prime} 55.68^{\prime \prime}$ & 695 \\
\hline
\end{tabular}

Table 2. Plant contents in essential oil and n-hexacosanol.

\begin{tabular}{lcc}
\hline Plant Source & $\begin{array}{c}\text { mg essential oil /100 g } \\
\text { plant }\end{array}$ & $\begin{array}{c}\text { mg hexacosanol/100 g } \\
\text { plant }\end{array}$ \\
\hline 1 Ponta do Pargo & 1730 & 144.12 \\
2 Calheta & 890 & 111.18 \\
3 Encumeada & 1730 & 252.72 \\
4a Ponta do Sol (Leaves) & 290 & 1.0 \\
4b Ponta do Sol (Flowers) & 2410 & 251.07 \\
5 Santo Serra & 700 & 48.65 \\
\hline
\end{tabular}

Table 3. Main chemical components of the analysed essential oils.

\begin{tabular}{lrrrrrr}
\hline Compounds & 1 & 2 & 3 & $4 \mathrm{a}$ & $4 \mathrm{~b}$ & 5 \\
\hline p-Cymene & 5,72 & 6,93 & 5,95 & 17,06 & 4,61 & 11,33 \\
Cis--b-ocimene & 1,14 & 5,34 & 0,58 & 4,11 & 0,56 & 2,51 \\
g-Terpinene & 11,31 & 20,49 & 8,66 & 11,7 & 10,38 & 19,61 \\
Thymol methyl ether & 3,38 & 6,91 & 1,84 & 12,23 & 1,96 & 7,11 \\
Carvacrol methyl ether & 2,91 & 4,36 & 4,13 & 3,78 & 2,89 & 1,19 \\
Thymol & 50,3 & 19,37 & 55,0 & 26,68 & 58,0 & 30,96 \\
Carvacrol & 2,86 & 1,39 & 6,75 & 0,5 & 1,14 & 1,36 \\
b-Caryophyllene & 7,08 & 9,07 & 5,3 & 6,29 & 6,08 & 6,44 \\
Germacrene D & 2,82 & 3,54 & 0,34 & 1,72 & 2,48 & 3,91 \\
Bisabolene & 5,05 & 3,54 & 3,13 & 3,51 & 4,96 & 2,01 \\
TOTAL & 92,57 & 80,94 & 91,68 & 87,58 & 93,06 & 86,43 \\
Total Phenolics & 59,45 & 32,03 & 67,72 & 43,19 & 63,99 & 40,62 \\
\hline
\end{tabular}


Table 4. Antimicrobial activity of Origanum essential oils.

\begin{tabular}{lcccccc}
\hline Microrganisms & 2 & 3 & $4 \mathrm{~b}$ & 5 & Rifampicin & 5-Fluorocytosine \\
\hline S. aureus & 50 & $50^{*}$ & 50 & 50 & 0.001 & n. t. \\
P. aeruginosa & $>200$ & $>200$ & $>200$ & $>200$ & $200^{*}$ & n. t. \\
M. smegmatis & $25^{*}$ & $25^{*}$ & $50^{*}$ & 100 & $0.5^{*}$ & n. t. \\
E. coli & 200 & $>200$ & 200 & 200 & 1.0 & n. t. \\
M. luteus & 100 & 200 & 200 & 200 & 0.01 & n. t. \\
S. faecium & $100^{*}$ & $100^{*}$ & $100^{*}$ & $100^{*}$ & $0.5^{*}$ & n. t. \\
L. monocytogenes & $100^{*}$ & $200^{*}$ & $200^{*}$ & $200^{*}$ & 0.07 & n. t. \\
C. albicans & $100^{*}$ & $200^{*}$ & 200 & 200 & n. t. & 5 \\
D. kloackeri & $50^{*}$ & $100^{*}$ & $100^{*}$ & $100^{*}$ & n. t. & 5 \\
R. rubra & $100^{*}$ & $100^{*}$ & $100^{*}$ & $100^{*}$ & n.t. & $5^{*}$ \\
\hline
\end{tabular}

* indicates bacteriostatic/fungistatic activity

Table 5. Radical Scavenging Capacity of essential oils determined by the DPPH reaction.

\begin{tabular}{lc}
\hline Sample & RSC $(\mu \mathrm{mol}$ Eq. Trolox/100 g EO $)$ \\
\hline 1 Ponta do Pargo & 260,71 \\
2 Calheta & 249,35 \\
3 Encumeada & 262,99 \\
4a Ponta do Sol Leaves & 240,97 \\
4b Ponta Sol Flowers & 263,64 \\
5 Santo da Serra & 259,31 \\
\hline
\end{tabular}


